JURNAL NUANSA

ISSN:2477-4103

KENOTARIATAN

\title{
Sengketa Perjanjian Jual Beli Tanah \\ Dalam Perkembangan Hukum Perjanjian Nasional: Perspektif Hakim
}

\author{
\}afar Chan*
}

Fauzie Yusuf Hasibuan**

\author{
*Universitas Jayabaya \\ **Universitas Jayabaya
}

\section{ARTICLE INFO \\ Keywords: \\ Purchase agreement, \\ discovery of the law,}

national contract law

Corresponding Author: adv_fauzie@yahoo.com

Nuansa Kenotariatan

Volume 1 Nomor 1

Juli-Desember 2015

ISSN. 2477-4103

hh. $1-10$
ABSTRACT

This research about the discovery of the law by the judge as stipulated in the rulings, particularly in the purchase agreement of land dispute has spawned some of the rules of law as well as annotation of the dedsion which not only applies to the parties that the litigants, but the rule of law and annotations such decision has contributed to the development of national contract law. This research using descriptive analytic conceptual approach for the rule of law is derived from the discovery of the law by judges and the rule of law was raised surface and serve as the rule of law which further guidance in terms of buying and selling land, espedally customary land.Implementation of the discovery of the law by the judge has given a positive contribution to the development of national legal development, particularly for the development of contract law that continues to evolve with the dynamic development of sodety.

Penelitian ini tentang penemuan hukum oleh hakim sebagaimana diatur dalam keputusan, khususnya dalam perjanjian pembelian sengketa tanah yang telah memunculkan beberapa aturan hukum serta penjelasan dari keputusan yang tidak hanya berlaku untuk pihak-pihak yang berperkara, namun dari aturan hukum dan penjelasan keputusan yang berkontribusi dalam perkembangan hukum kontrak Nasional. Penelitian ini menggunakan pendekatan konseptual deskriptif analitik untuk aturan hukum yang berasal dari penemuan hukum oleh hakim dan aturan hukum yang diangkat ke permukaan dan berfungsi sebagai aturan hukum yang mendapatkan panduan lebih lanjut dalam hal jual beli tanah, terutama adat tanah. Pelaksanaan penemuan hukum oleh hakim telah memberikan kontribusi positif bagi perkembangan pembangunan hukum nasional, terutama untuk perkembangan hukum kontrak yang terus berkembang dengan dinamika perkembangan masyarakat

@2015 NK. All rights reserved. 


\section{Pendahuluan}

Undang-undang tidak ada yang sempurna karena tidak mungkin ada suatu undang-undang yang mengatur segala kegiatan manusia secara lengkap dan tuntas. Adakalanya suatu undang-undang tidak lengkap dan adakalanya undang-undang tidak jelas. Meskipun suatu undang-undang tidak lengkap dan ti.dak jelas mengatur sesuatu, tetapi undang-undang itu tetap harus dilaksanakan Dalam hal terjadi suatu pelanggaran undang-undang, maka hakim ti.dak dapat menolak atau menangguhkan serta menunda pelaksanaan dan termasuk penegakan undang-undang tersebut (Hiariej, 2009).

Dengan situasi dan kondisi di atas, maka sudah tentu hakim harus mempelajati dan mencati jalan dengan berbagai cara penemuan hukum yang memang sudah disediakan oleh ilmu hukum, karena kewajiban menemukan hukum ini sudah merupakan kewajiban yang harus dijalankan oleh hakim dalam mengemban tugas luhumya (Ardhiwisastra, 2008).Secara faktual , undang-undang umumnya tidak lengkap dan ti.dak jelas, maka dalam suatu peristiwa hukum tertentu, hakim harus menemukan hukumnya atau dengan kata lain hakim harus melakukan penemuan hukum (rechtsvinciing) untuk menjawab berbagai persoalan hukum yang ada dan diajukan dihadapannya (Monteiro, 2007).

Scolten (Rahardjo, 2006) menyebutkan bahwa hukum itu ada, tetapi masih harus ditemukan dalam penemuan itulah terdapat yang baru. Sesuatu yang khayal apabila orang beranggapan bahwa undangundang itu telah mengatur segalanya secara tuntas. Dalam penemuan hukum ditemukan suatu hal yang baru yang dapat dilakukan, baik lewat penafsiran, analogi, maupun penghalusan hukum (rechtsverftjning). Perbedaan makna antara penemuan hukum (rechtsvinding) dan istilah penerapan hukum (rechtstoepassing ) (Mertokusumo, 2009). Kedua istilah tersebut memiliki pengertian dan lapangan peninjauan yang berbeda.

Secara nyata penemuan hukum oleh hakim lebih banyak mendapat perhatian yang dilatarbelakangi asas ius curia novit bahwa "hakim lebih tahu akan hukumnya", di samping anggapan umum bahwa hakim merupakan gerbang terakhir bagi pencati keadilan. Kewenangan penemuan hukum itu dalam praktik peradilan yang disebut rechtsvinding muncul sebagai konsekuensi dati implementasi negara hukum (recht staat) yang memberikan perwujudan dati tujuan hukum yakni, keadilan, kepastian hukum dan kemanfaatan. Dalam penjabaran selanjutnya kewenangan penemuan hukum dimaksud ditegaskan pula di da- lam Pasal 24 ayat (1) dan ayat (2) Undang-Undang Dasar 1945 (selanjutnya disingkat dengan UUD1945) dan dalam Pasal 28 ayat (1) UU No.4 Tahun 2004 tentang Kekuasaan Kehcl:<i.man serta perkembangan perundang-undangan yang terakhir tertera di dalam ketentuan Pasal10 ayat (1) Undang-Undang Nomor 48 Tahun 2009, tentang Kekuasaan Kehakiman sebagai pengganti UU No.4 Tahun 2004.

Praktik penemuan hukum bukanlah suatu proses yang logis belaka melalui subsumpsi dati fakta pada ketentuan undang-undang saja, akan tetapi juga adalah ti.ndakan dalam penilaian-penilaian dati fakta untuk kemudian menemukan hukumnya (Loudoe, 1985). Peristiwa hukum membutuhkan metode penemuan hukum agar aturan hukumnya dapat diterapkan secara tepat terhadap peristiwcmya, sehingga dapat diwujudkan suatu putusan hakim yang mencerminkan aspek kepastian hukum (rechtssicherheit), keadilan (gerectigkeit) dan kemanfaatan (zweckmassigkeit) di dalamnya (Sutiyoso, 2006; Mertokusumo dan Pitlo, 1993).

Jika di dalami, maka asumsi yang sangat mendasar yang dipergunakan untuk hal di atas dilatarbelakangi adanya anggapan bahwa penemuan hukum dilakukan karena hukumnya tidak lengkap atau tidak jelas, maka hukumnya harus dicari dan diketemukan (Mertokusumo, 2009). Kegiatan inilah yang di dalam ilmu hukum dikenal dengan istilah penemuan hukum (rechsvinding), yang berintikan konkriti.sasi, kristalisasi dan individualisasi dari peraturan hukum (das sollen) yang bersifat umum dengan mengingat peristiwa konkritnya (das sein). Peristiwa konkrit itu harus dicarikan atau dipertemukan dengan hukumnya (Mertokusumo, 2009).

Bahwasanya membuat (menciptakan) hukum adalah suatu hal dan menafsirkan hukum yang sudah dibuat merupakan keharusan pula (Rahardjo, 2009). Problematika sentral yang berhubungan dengan penemuan hukum umumnya dipusatkan pada hakim dan pembentuk undang-undang. Penemuan hukum, terutama yang dilakukan oleh hakim bahwasanya penemuan hukum lazimnya adalah proses pembentukan hukum oleh hakim atau aparat hukum lainnya yang ditugaskan untuk penerapan peraturan hukum umum pada peristiwa konkrit. Lebih jauh penemuan hukum merupakan proses konkritisasi atau individualisasi peraturan hukum yang bersifat umum dengan mengingat akan peristiwa konkrit tertentu (Amo 2008; Mertokusumo,2009; Murad, 2005; Suti.yoso, 2006). 
Penemuan hukum (rechtsvinding) yang dikemukakan, pada dasamya merupakan proses pembentukan hukum oleh subyek atau pelaku penemuan hukum dalam upaya menerapkan peraturan hukum umum terhadap peristiwanya berdasarkan kaidah-kaidah atau metode-metode tertentu yang dapat dibenarkan dalam ilmu hukum, seperti interpretasi, penalaran (redenering), eksposisi (konstruksi hukum) dan lainnya (Hamidi, 2005). Metode penemuan hukum dilakukan untuk penerapan hukum terhadap suatu peristiwa hukum sehingga dapat dilakukan secara tepat dan akurat serta relevan menurut hukum, sehingga hasil yang diperoleh dalam proses penemuan hukum itu dapat diterima dan dipertanggungjawabkan (disediakan) dalam ilmu hukum (Pound, 1973; Rifai, 2010).

Pelaku atau subyek dalam pelaksanaan penemuan hukum dapat dilakukan oleh individu (perorangan), ilmuwan hukum atau peneliti hukum, para penegak hukum (Hakim, Jaksa, Polisi, Advokat, Notaris dan sebagainya). Namun dalam diskursus penemuan hukum, maka yang lebih banyak dibicarakan adalah penemuan hukum yang dilakukan oleh hakim, oleh pembentuk undang-undang dan peneliti atau yang dilakukan para ahli hukum (Sutiyoso, 2006).

Hakim selaku salah satu subyek penemuan hukum, melaksanakan penemuan hukum, manakala ia dihadapkan pada peristiwa konkrit atau suatu konflik untuk diselesaikannya, jadi sifatnya konfliktif, dan hasil penemuan hukumnya merupakan atau berwujud hukum, karena substansinya memiliki kekuatan mengikat sebagai hukum yang dituangkan dalam bentuk putusannya, khususnya bagi pihak-pihak yang tertera dalam putusannya tersebut. Hasil penemuan hukum oleh hakim ini sekaligus merupakan sumber hukum juga. Untuk hal ini, maka hakim harus menelaah sumber-sumber penemuan hukum, yang tidak lain adalah sumber atau tempat hukumnya. Adapun sumber utama penemuan hukum adalah: (1) peraturan perundang-undangan; (2) kebiasaan; (3) yurisprudensi; (4) perjanjian intemasional; (5) doktrin (Sutiyoso, 2006).

Sumber hukum dalam penemuan hukum sekaligus juga menunjukkan adanya hirarki dan jenjang dalam mempergunakan sumber hukum, ada tingkatantingkatan dalam penggunaanya (Sutiyoso, 2006). Oleh karena itu jika terjadi konflik dua sumber hukum, maka sumber hukum yang tertinggi melumpuhkan sumber hukum yang Iebih rendah (Mertokusumo, 2009). Hirarki tentang sumber hukum dalam pelaksanaan penemuan hukum harus diartikan bahwa tidaklah menempatkan posisi antara sumber hu- kum yangsatu lebih tinggi derajatnya dari pada yang lain, tetapi prioritas penggunaanyalah yang lebih diutamakan atau didahulukan secara berjenjang mulai dari sumber hukum perundang-undangan (hukum tertulis) dan seterusnya. Dengan demikian bahwa walaupun sumber hukum perundang-undangan (hukum tertulis) lebih diutamakan penggunaannya, bukan berarti sumber-sumber hukum lainnya diabaikan. Keseluruhan sumber hukum dalam pelaksanaan penemuan hukum pada prinsipnya saling melengkapi dan bersinergi satu sama lainnya.

Penemuan hukum (rechtsvinding) terutama dalam hal ini yang dilakukan oleh hakim merupakan pengejawantahan dari tiga situasi dan kondisi yang dihadapinya, yaitu: (a) terjadinya kekosongan hukum (rechts vacuum); (b) terjadinya kekosongan undang-undang (wet vacuum) dan; (c) setiap kegiatan hakim dalam memeriksa, memutus suatu perkara yang diajukan ke hadapan hakim.

Sebagai wujud suatu negara hukum, (rechtsstaat) maka negara dalam mewujudkan tujuan hukum, yakni memberikan keadilan, kepastian hukum dan kemanfaatan, maka implementasi penemuan hukum terutama oleh hakim seyogianya dapat memberikan kontribusi perwujudan tujuan hukum tersebut.

Berdasarkan ketentuan perundangan-undangan,tentang kekuasaan Kehakiman secara konstitusional diatur dalam Bab IX, Pasal 24, pasal 24A,Pasal 24B,24C dan Pasal 25 Undang-Undang Dasar 1945; (2) dalam PasalS dan Pasal14 ayat (1) Undang-Undang Nomor. 4 Tahun 2004 tentang Kekuasaan Kehakiman; (3) dalam Pasal 4 dan Pasal 10 ayat (1) Undang-Undang Nomor 48 Tahun 2009 tentang Kekuasaan Kehakiman.

Dalam ketentuan perundang-undangan, khususnya secara jelas termuat dalam Pasal10 ayat (1) UndangUndang Nomor.48 Tahun 2009 yang secara tegas menyebutkan bahwa pengadilan dilarang menolak untuk memeriksa, mengadili, dan memutus suatu perkara yang diajukan dengan dalih bahwa hukum tidak ada atau kurang jelas, melainkan wajib untuk memeriksa dan mengadili. Makna pasal-pasal tersebut menunjukkan bahwa alasan hukum tidak mengatumya atau hukumnya kurang jelas tidak menjadikan hakim dapat menolak suatu perkara yang diajukan di hadapan hakim dan ini berhubungan dengan asas hukum bahwasanya hakim dianggap tahu akan hukumnya(ius curia novit).

Dengan situasi dan kondisi demikian yang dihadapi hakim, baik itu situasi kekosongan undang-undang (wet vacuum), kekosongan hukum (wet vacuum) 
serta perlu perluasan makna suatu ketentuan yang kurang jelas, maka hakim dengan berpijak pada ketentuan perundang-undangan wajib menemukan hukumnya, yaitu mempertemukan suatu peristiwa konkrit kepada hukumnya. Kegiatan ini yang disebut sebagai penemuan hukum (rechtsvinding) oleh hakim.

Penemuan hukum dengan berpijak pada ketentuan perundang-undangan di atas, jelas menunjukkan bahwa prioritas pelaksanaan penemuan hukum, umumnya dilakukan oleh hakim dan bukan dilakukan oleh aktor hukum lain (Jaksa, Pengacara, Notaris, ahli hukum, dosen dan para juristen lainya) yang juga melakukan kegiatan penemuan hukum dengan perbedaan pada hasil penemuan hukumnya.

Penemuan hukum (rechtsvinding) adalah proses pembentukan hukum oleh hakim atau petugas-petugas hukum lainnya yang diberi tugas menerapkan hukum terhadap peristiwa-peristiwa hukum yang konkrit. Dengan katalain, penemuan hukum merupakan proses konkritisasi atau individualisasi peraturan hukum yang bersifat umum dengan mengingat akan peristiwa konkrit tertentu.

Kontribusi dari hasil penemuan hukum ini, merupakan wujud dalam menyikapi perkembangan dan kebutuhan hukum masyarakat dan hasil penemuan hukum dalam jangkauan yang lebih jauh diharapkan juga mampu melahirkan norma dan asas-asas hukum yang dapat dijadikan landasan bagi pembentukan atau penciptaan hukum yang baru, termasuk pelaksanaan hukum untuk ke depannya, terutama dalam suatu kasus tertentu (in case) dan hasil penemuan hukum melahirkan asas-asas hukum dan norma-norma yang dapat dijadikan landasan sebagai pembentukan hukum baru (ius costituendum) di masa yang akan datang atau ius constitut!ndum ini yang dicita-citakan dalam memenuhi kebutuhan hukum masyarakat. Selengkapnya kerangka fikir dalam penelitian ini terangkum dalam bagan dibawah ini.

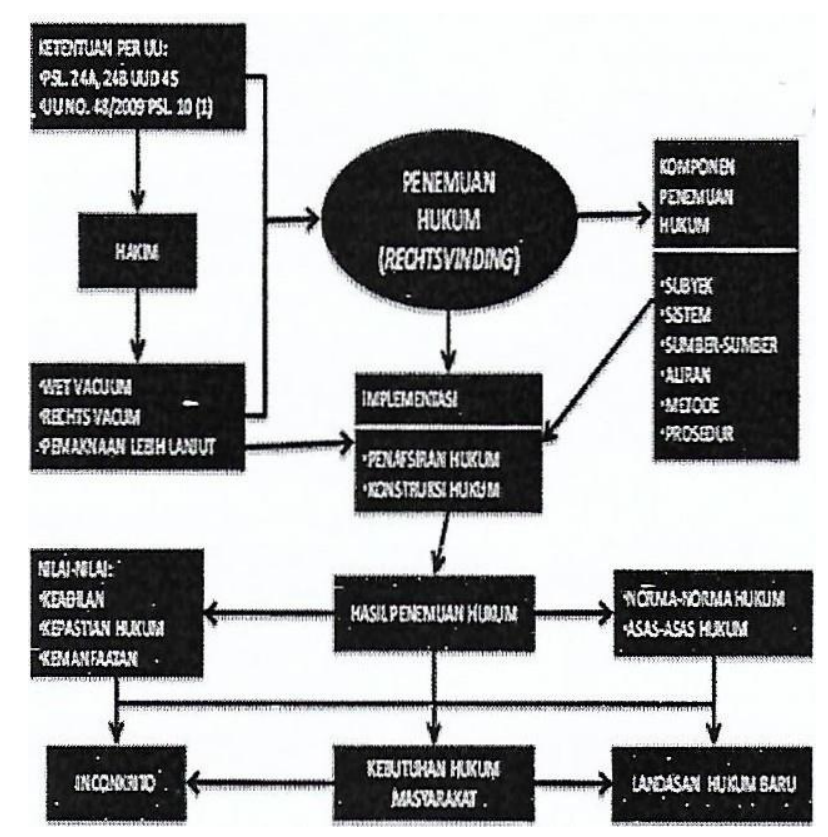

Gambar 1. Bagan Kerangka Pikir Penelitian

\section{Metodologi Penelitian}

Penelitian ini diarahkan sebagai suatu penelitian yang bersifat deskriptif analitik dengan pendekatan konseptual (conceptual approach) dan sasaran yang hendak dicapai adalah penelaahan secara sistematis tentang penemuan hukum yang dilakukan oleh hakim dalam bidang perjanjian jual beli tanah dan kontribusi positifnya bagi perkembangan hukum perjanjian nasional (Soekanto, 2008; Nasution, 2008).
Deskriptif analitik memberikan peluang dalam penelitian ini untuk menggambarkan secara utuh dan menyeluruh proses yang hendak diwujudkan dalam menjawab asumsi atau pertanyaan-pertanyaan penelitian yang diajukan. Bentuk penelitian ini adalah penelitian hukum norrnatif atau disebut juga dengan penelitian hukum doktrinal dan ada juga ahli yang menyebut dengan penelitian hukum kepustakaan yang secara umum mencakup penelitian hukum terhadap asas-asas hukum, kaidah-kai- 
dah hukum, peraturan hukum konkrit dan sistem hukum (Fajar dan Ahmad, 2010; Marzuki, 2005; Wigyosubroto, 2002; Soekanto dan Mamudji, 1995). Berdasarkan tingkatan penelitian yang dilakukan, maka kategori tingkatan penelitiannya merupakan penelitian pengembangan, yaitu penelitian yang bertujuan mengembangkan masalah (Soetriono dan Hanafie, 2007; Soekanto, 2008).

Sumber bahan dalam penelitian hukum normati£ umumnya dipergunakan tiga jenis data hukum, yaitu: (1) data hukum primer, yakni data hukum yang bersifat mengikat atau utama yang terdiri dari:(a) berbagai putusan hakim yang telah menjadi yurisprudensi yang ada di Mahkamah Agung yang dikhususkan yurisprudensi tentang sengketa perjanjian jual beli dengan obyek sengketanya adalah tanah; (b) berbagai ketentuan perundang-undangan yang berkaitan erat kaitannya dengan pembahasan kewenangan hakim dan termasuk juga dasar pijakan bagi hakim yaitu: (i) Undang-Undang Nomor.48 Tahun 2009 tentang Kekuasaan Kehakiman, termasuk juga meninjau Undang-Undang Nomor.14 tahun 1970 jo Undang-Undang Nomor. 4 Tahun 2004 tentang Ketentuan-Ketentuan Pokok Kekuasaan Kehakiman (lama);(ii) UU Nomor.14 Tahun 1985 jo UU Nomor.S Tahun 2004 tentang MahkamahAgung dan UU No.3 Tahun 2009 tentang Perubahan Kedua Atas UU Nomor 14 Tahun 1985 tentang MahkamahAgung; (iii) UU Nomor.2 Tahun 1986 jo UU Nomor.8 Tahun 2004 tentang Peradilan Umum dan UU Nomor 49 Tahun 2009 tentang Perubahan Kedua Atas UU Nomor.2 Tahun 1986 tentang Peradilan Umum; (c) berbagai peraturan Mahkamah Agung Republik Indonesia dan termasuk juga Surat Edaran Mahkamah Agung Republik Indonesia yang berkaitan erat dengan halhal yang akan diteliti; (d) kitab himpunan putusan hakim yang telah menjadi yurisprudensi, baik yang diterbitkan oleh Mahkamah Agung, maupun diterbitkan oleh penerbitan lainya yang telah beredar luas di masyarakat. (2) bahan hukum sekunder, atau bahan hukum yang memberL"'‘an penjelasan mengenai data hukum primer, antara lain: (a) berbagai kepustakaan mengenai penemuan hukum, tentang yurisprudensi, tentang hukum responsif; (b) disertasi yang telah dibukukan mengenai penemuan hukum; (c) kepustakaan mengenai penafsiran hukum; (d) berbagai kepustakaan lain yang menyangkut dan relevan tentang penemuan hukum, yurisprudensi dan hukum progresif serta tentunya tentang perikatan pada umumnya;(3) bahan hukum tertier yaitu bahan yang memberi petunjuk dan penjelasan terhadap bahan hukum primer dan sekunder yang antara lain bersumber dari surat kabar, majalah, jur- nal, buletin mingguan, bulanan, kamus hukum, kamus bahasa Indonesia.

\section{Hasil Penelitian dan Pembahasan}

Pembahasan yang sangat mendasar tentang kebutuhan penemuan hukum (rechtsvinding) ini sebenarnya secara holistik atau menyeluruh mempertanyakan tentang ini penting sehubungan dengan asumsi dasar dalam membicarakan tentang penemuan hukum, maka pembahasannya dapat dilakukan dengan menelusuri dua pandangan besar (Ali, 2008) pulayaitu:

\section{Doktrin Sens-Clair (la doctrine du sensclair)}

Penganut aliran ini berpendapat bahwa penemuan hukum oleh hakim hanya dibutuhkan jika: (a) peraturannya belum ada untuk suatu kasus inconcreto, atau; (b) peraturannya sudah ada, tetapi belum jelas; Penganut aliran ini memandang bahwa di luar dari dua kondisi di atas, maka penemuan hukum oleh hakim tidak ada, atau hakim tidak melakukan penemuan hukum.

Kerckhove (Ali, 2008) menyimpulkan bahwa doktrin sens-clair ini ke dalam lima hal pokok, yaitu: (a) ada teks undang-undang yang dimengerti maknanya sendiri dan berdasarkan setiap penjelasan sebelumnya serta tidak mungkin menimbulkan keraguan; (b) karena bahasa hukum didasarkan pada bahasa percakapan sehari-hari, maka dapat dianggap semua istilah yang tidak ditentukan oleh pembuat undang-undang tetap saja sama artinya dengan yang dimiliki dalam bahasa percakapan sehari-hari; (c) kekaburan suatu teks undang-undang hanya mungkin terjadi karena mengandung dua arti (ambigurasi) atau karena kekurangan tetapan arti yang lazim dari istilah-istilah itu; (d) secara ideal, biasanya yang dijadikan pegangan bagi pembuat undang-undang adalah ia harus merumuskan teks undang-undang dengan sejelas-jelasnya. Kekaburan teks harus dihindari, juga jangan sampai terjadi perumusan yang kurang baik;(e) untuk mengetahui adanya kekaburan atau pun tidak adanya kekaburan teks undang-undang tidak diperlukan penafsiran. Sebaliknya, pengakuan tentang jelas atau kabumya teks menghasilkan kriteria yang memungkinkan untuk menilai apakah suatu penafsiran atau penemuan hukum memang atau tidak diperlukan. Jika diperlukan atau tidak diperlukan, hasilnya dalam penetapan hukum adalah sah.

Doktrin Sen-clair ini secara implisit tidak menghendaki hakim melakukan penemuan hukum atau juga melakukan penafsiran hukum 
Aliran penemuan hukum selalu (harus) dilakukan hakim

Aliran ini memiliki pandangan bahwasanya hakirn. selalu dan tidak pemah tidak melakukan penemuan hukum. Latar belakang dari pandangan ini adalah terhadap aturan-aturan yang sudah jelas sekalipun dan tidak memerlukan penafsiran merupakan pandangan yang tidak dapat diterima. Bukan hanya peraturan-peraturan yang kurang jelas yang membutuhkan penafsiran atau konstruksi hukum, melainkan semua peraturan membutuhkan, paling tidak penafsiran jika ingin diterapkan dalam suatu peristiwa yang bersifat in-concreto. Pandangan ini menganggap bahwa semua putusan hakim merupakan hasil penemuan hukum, apakah itu melalui penafsiran hukum, konstruksi hukum, penghalusan atau pengkonkritan hukum dengan tidak memandang apakah peraturan itu sudah jelas atau kurang jelas atau termasuk juga apakah hukumnya ada atau hukumnya tidak ada mengatur tentang sesuatu hal (Ardhiwisastra, 2008; Mertokusumo, 2009;Ali, 2008; Rifai, 2010;Sutiyoso, 2006).

Penemuan hukum (rechtsvinding) melalui putusan hakim merupakan implementasi dari prinsip bahwa hakim tidak boleh menolak perkara dengan alasan hukumnya tidak jelas atau hukumnya tidak ada dan hakim berkewajiban penuh untuk harus mengisi kekosongan hukum (rechtsvacuum) termasuk juga dalam hal ini untuk mengisi kekosongan perundang-undangan (wetvacuum). Hakim wajib mengali, mengikuti dan memahami nilai-nilai hukum yang hidup di masyarakat. Dengan kata lain, hakirn. dianggap tahu akan hukumnya (ius curia novit).

Bertitik tolak dalam perkembangan hukum perjanjian saat ini, maka setidaknya ada tiga sumber penyebab terjadinya sengketa dalam bidang perjanjian (Pangabean, 2008), yaitu:

1. Tentang keabsahan suatu perjanjian (validity of contract), yaitu sumber sengketa umumnya terjadi jika suatu perjanjian yang di dalamnya megandung unsur-unsur penipuan (bedrog), paksaan (dwaling) dan atau adanya ancaman keadaan (undue influence);
2.Tentang pemenuhan perjanjian (performance of contract), yaitu sumber sengketa terjadi manakala salah satu pihak melakukan wanprestasi atau karena adanya unsur perbuatan melawan hukum (onrechtmatigedaadltort) atau suatu keadaan memaksa (force majeure);

3. Tentang pelaksanaan perjanjian, di mana sumher sengketa terjadi salah satu pihak melakukan perbuatan melawan hukum, melakukan wanprestasi dan atau karena keadaan memaksa;

Sehubungan dengan ketiga hal di atas dan dikaitkan dengan fokus pembahasan untuk penelitian ini, maka terhadap sengketa jual beli dengan obyek sengketa berupa tanah yang dihubungkan dengan perspektif penemuan hukum oleh hakim, maka dasar sengketanya dapat diklasifikasikan ke dalam pola-pola sengketa sebagai berikut:

1. Sengketa tentang jual beli tanah adat;

2. Sengketa perihal syarat sahnya jual beli tanah;

3. Sengketa tentang sahr..ya jual beli tanah;

4. Sengketa tentang jual beli dengan hak membeli kembali;

5. Sengketa tentang keabsahan jual beli tanah.

.Klasifikasi atas pola-pola sengketa jual beli dengan obyeknya tanah di atas didukung fakta bahwa, berdasarkan data perkara dalam klasifikasi yurisprudensi, maka sengketa bidang pertanahan menempati tingkatan terbanyak, sehingga diperlukan suatu bentuk klasif.kasi sengketa tersebut berdasarkan karakteristik sengketanya, karakteristik kaidah hukum dalam obyek sengketa serta tentunya anotasi yang muncul dalam substansial putusan hakirn..

Dari hasil klasifikasi sengketa dan pokok gugatan yang telah dilakukan terhadap beberapa keputusan hakim yang sudah menjadi yurisprudensi, khususnya yang sudah menjadi yurisprudensi tetap atau yurisprudensi biasa, maka hasil penelahan tentang hal ini, khusus peninjauannya di fokuskan dalam sengketa dalam jual beli tanah terhadap yurisprudensi Mahkamah Agung dimaksud, dapat dibuatkan urutannya dalam bentuk tabulasi seperti yang terangkum pada tabel di bawah ini: 
Tabel Klasifikasi Pokok Perkara dan Nomor Perkara Sengketa Jual Bell Tanah yang sudah menjadi Yurisprudensi Tetap maupun Yurisprudensi Biasa

\begin{tabular}{|c|c|}
\hline Klasiftkasi Dan Pokok Gugatan & Nomor Perkara (Yurisprudensi) \\
\hline \multirow{7}{*}{ Sengketa tentang Jual bell tanah adat } & MA Nomor: 237 K/Sip/1968 \\
\hline & MA Nomor: 75 K/Pdt/1970 \\
\hline & MA Nomor: 1589 K/Pdt/1986 \\
\hline & MA Nomor: 1132 K/Pdt/1987 \\
\hline & MA Nomor: 674 K/Pdt/1989 \\
\hline & MA Nomor: 1115 K/Pdt/1996 \\
\hline & MA Nomor: $1363 \mathrm{~K} / \mathrm{Pdt} / 1996$ \\
\hline \multirow{6}{*}{$\begin{array}{l}\text { Sengketa tentang Syarat sahnya jual bell } \\
\text { tanah }\end{array}$} & MA Nomor: 147 K/Sip/1970 \\
\hline & MA Nomor: 507 K/Sip/1976 \\
\hline & MA Nomor: 1253 K/Sip/1983 \\
\hline & MA Nomor: $1250 \mathrm{~K} / \mathrm{Pdt} / 1986$ \\
\hline & MA Nomor: 3247 K/Pdt/1987 \\
\hline & MA Nomor: 3274 K/Pdt/1987 \\
\hline \multirow{4}{*}{ Sengketa tentang Sahnya Jual bell Tanah } & MA Nomor: $126 \mathrm{~K} / \mathrm{Sip} / 1976$ \\
\hline & MA Nomor: 665 K/Sip/1979 \\
\hline & MA Nomor: $1341 \mathrm{~K} / \mathrm{Sip} / 1982$ \\
\hline & MA Nomor: 3352 K/Pdt/1984 \\
\hline \multirow{3}{*}{$\begin{array}{l}\text { Sengketa tentang Jual bell dengan Hak } \\
\text { membeli kembali }\end{array}$} & MA Nomor: $3804 \mathrm{~K} / \mathrm{Sip} / 1981$ \\
\hline & MA Nomor: 2485 K/Sip/1982 \\
\hline & MA Nomor: 3597 K/Pdt/1985 \\
\hline \multirow{5}{*}{$\begin{array}{l}\text { Sengketa tentang Keabsahan Jual bell } \\
\text { tanah }\end{array}$} & MA Nomor: 1252 K/Sip/1983 \\
\hline & MA Nomor: $1250 \mathrm{~K} / \mathrm{Pdt} / 1986$ \\
\hline & MA Nomor: 3274 K/Pdt/1988 \\
\hline & MA Nomor: 3176 K/Pdt/1988 \\
\hline & MA Nomor: 318 PK/Pdt/1988 \\
\hline
\end{tabular}

Sehubungan dengan pembahasan sengketa jual beli yang dihubungkan dengan perspektif penemuan hukum, maka dalam pembahasan berikut akan ditinjau anotasi putusan hakim sebagai output dari pelaksanaan penemuan hukum oleh hakim, yaitu:

Anotasi putusan hakim tentang sengketa jual beli tanah adat dalam putusan Mahkamah Agung Nomor.237 K/Sip/1968.

Dalam putusan Mahkamah Agung Nomor.237 Kj Sip/1968 anotasi utama yang muncul kepermukaan dalam putusan ini adalah perwujudan tujuan hukum pada bentuk kepastian hukum (rechtssicherheit) dan keadilan (gerectigkeit). Makna yang sangat esensi dalam kandungan anotasi putusan hakim tersebut adalah bahwasanya hakim dengan menggunakan metode penafsiran dan konstruksi hukum telah menemukan suatu hal yang sifatnya esensi yaitu suatu prinsip yang hidup di dalam masyarakat, khususnya masyarakat hukum adat bahwa dalam hal jual beli prinsip terang dan tunai (contante handeling) akan memberikan suatu kepastian hukum bagi masyarakat hukum adat dan sekaligus perwujudan keadilan bagi masyarakat hukum adat dalam meIaksanakan perbuatan hukum berupa jual beli tanah adat milik mereka. Prinsip atau konsep tunai dan terang lebih tepat untuk dilaksanakan dalam perbuatan hukum jual beli tanah yang dilakukan sebagian masyarakat hukum adat kita terlebih jika berhadapan dengan pihak-pihak luar, baik itu investor nasional maupun asing.

Dalam hal impelementasi dari prinsip jual beli tanah adat terang dan tunan (contante handeling) ini tidak sepenuhnya dilaksanakan, maka akan banyak permasalahan yang timbul di kemudian hari dan akibatnya akan merugikan kedua belah pihak, terutama sekali dirasakan oleh pihak masyarakat hukumadat.

Dengan penemuan hukum oleh hakim sebagaimana tertuang dalam putusan Mahkamah Agung Nomor.237 K/Sip/1968 di atas, prinsip jual beli tanah adat terang dan tunai merupakan prinsip yang terus dipedomani dalam hal jual beli tanah adat sampai saat ini. Artinya hakim telah menemukan hukum yang mencerminkan perwujudan akan kepastian hukum dan perwujudan keadilan bagi masyarakat hukum adat dalam hal perbuatan hukum jual beli 
tanah adat dan menempatkan posisi yang setara antara para pihak.

Anotasi kepastian hukum diambil oleh hakim sebagai perwujudan penemuan hukumnya cenderung untuk mempertahankan norma-norma hukum yang ada dalam suatu masyarakat hukum adat yang umumnya tidak tertulis, sedangkan anotasi keadilan menekankan juga pada pertimbangan utama pada perwujudan hukum yang hidup di masyarakat yang terdiri dari kebiasaan-kebiasaan dan ketentuan-ketentuan hukum yang tidak tertulls yang sangat berperan di dalam suatu kesatuan masyarakat hukum adat.

Anotasi putusan tentang syarat sahnya jual beli tanah seperti tertuang dalam putusan Mahkamah Agung Nomor.147 I</Sip/1970

Anotasi putusan ini memberikan pedoman bahwasanya cacat hukum dalam jual bell tanah dapat terjadi dalam dua aspek, yaitu: (1) aspek formal karena tata cara pembuatan yang tidak sesuai dengan prosedur yang berlaku; (2) aspek materiil karena salah satu pihak melakukan itikad buruk. Anotasi putusan hakim tersebut merupakan implementasi dari kaidah hukum yang terkandung di dalam putusan hakim dimaksud di mana dinyatakan bahwasanya untuk sahnya jual bell tanah tidak dapat didasari unsure cacat hukum, yaitu baik baik cacat hukum formal maupun cacat hukum materiil.

Anotasi putusan tentang sahnya jual beli tanah sesuai dengan putusan Mahkamah Agung No.126 K/Sip/1976 yang melahirkan kaidah hukum bahwasanya jual beli tanah sah meskipun tidak di hadapan Pejabat Pembuat Aida tanah.

--1 Inotasi putusan Mahkamah Agung ini mengambarkan bahwa dalam sistem hukum adat pendaftaran melalui Pejabat Pembuat Akta Tanah (PPAT) Iebih bersifat administratif saja dan sekaligus anotasi mewujudkan suatu bentuk keadilan dan kepatutan di dalam masyarakat, khususnya pada masyarakat hukum adat yang faktualnya masih banyak yang tidak mengetahui akan prosedural yang bersifat administratif dalam hal perbuatan hukum mengenai tanah.

Anotasi yang terkandung dalam perjanjian jual beli dengan hak membeli kembali, sesuai dengan putusan Mahkamah Agung Nomor.3804 KI Sip/1981

Anotasi yang secara general melahirkan kaidah hukum yang menyatakan bahwasanya perjanjian jual beli tanah yang masih banyak dikuasai hukum adat dan hukum adat tidak mengenal bentuk perjanjian jual beli dengan hak membeli kembali ini. Anotasi yang muncul dalam putusan tentang perjanjian ini telah menerapkan tiga aspek dari tujuan hukum, yakni kepastian hukum, keadilan dan kemanfaatan, sehingga putusan ini merupakan bentuk putusan yang dapat merealisasikan tiga tujuan hukum sekaligus dan untuk itu layak dipedomani untuk penerapan dalam kasus yang serupa.

Anotasi yang muncul dalam putusan Mahkamah Agung dalam putusannya No.12521</Sip/1983 sehubungan dengan keabsahan jual beli,

Anotasi ini di mana kaidah hukum yang muncul adalah bahwa jual bell tanah yang dilakukan di hadapan Camat yang belum mendapat SK Menteri Dalam Negeri adalah tidak sah dan harus dibatalkan. Anotasi yang terlihat dalam putusan tersebut adalah bahwa putusan ini memuat kandungan aspek kepastian hukum yang berpedoman pada aspek persyaratan materiil dalam suatu perjanjian.

Anotasi tentang keabsahan jual beli tanah sebagaimana putusan Mahkamah Agung Nomor.3176 K/Pdt/1988 yang mengandung kaidah hukum bahwa sebidang tanah yang ada sertifikatnya tidak dapat diperjualbelikan dengan begitu saja dengan surat girik.

Anotasi yang muncul dalam putusan ini yang menekankan pada aspek kepastian hukum dan secara substansial pula mempertimbangkan aspek formal penerbitan sertifikat hak atas tanah bagi seseorang

Anotasi putusan Mahkamah Agung Nomor.318 PK/Pdt/1988 yang mengandung kaidah hukum bahwasanya jual beli tanah yang tidak mendapat ijin dari instansi yang bersangkutan atau berwenang adalah batal.

Anotasi yang muncul kepermukaan dari putusan tersebut adalah bahwa putusan ini telah mempertimbangkan aspek materiil untuk keabsahan perjanjian jual beli.

Dari pembahasan ringkas di atas secara keseluruhan dapat ditarik suatu perkembangan tentang perspektif penemuan hukum dalam sengketa jual beli tanah yaitu, Pertama, penemuan hukum oleh hakim yang hasilnya tertuang dalam putusan hakim melahirkan kaidah-kaidah hukum tertentu yang sifatnya konkrit untuk suatu kasus tertentu dan putusan tersebut mengandung anotasi yang merupakan per- 
wujudan dari tujuan hukum utama, yaitu keadilan, kepastian hukum dan kemanfaatan yang dalam implementasinya jarang sekali dapat diterapkan ketiganya dalam suatu putusan hakim.

Kedua, Kaidah-kaidah hukum yang merupakan salab satu perwujudan penemuan hukum oleh hakim pada intinya muncul dengan proses yang panjang oleh hakim dengan menggunakan metode penafsiran hukum ataupun menggunakan metode konstruksi hukum. Kaidah hukum ini yang merupakan "roh" dari basil penemuan hukum oleh hakim yang selanjutnya melahirkan anotasi dalam putusan tersebut.

Ketiga, Penemuan hukum oleh hakim yang inti pelaksanaannya bersifat konkrit untuk suatu kasus tertentu, namun dalam pandangan yang lebih jauh, kaidah hukum dan anotasi yang ada dapat diterapkan secara general untuk kasus yang sama, terlebih hasil penemuan hukum oleh hakim tersebut berupa putusan hakim yang telah menjadi yurisprudensi tetap, walaupun dalam sistem hukum kita ada ketentuan bahwa seorang hakim tidak ada kewajiban baginya untuk dipedomani atau mengikuti putusan hakim lain dalam keputusannya.

Keempat, Pelaksanaan penemuan hukum oleh hakim, khususnya dalam sengketa jual bell tanah ini akan semakin berkembang sejalan dengan perkembangan fungsi dan kebutuhan tanah dalam pembangunan di segala bidang terus meningkat dan hakim dituntut untuk terus melakukan penemuan hukum sebagai terobosan, baik itu untuk penemuan hukum untuk mengisi kekosongan hukum (recht Vaccum) maupun penemuan hukum untuk mengisi kekosongan undang-unda11g (wet Vaccum).

\section{Kesimpulan}

Impelementasi penemuan hukum oleh hakim yang tertuang dalam putusan hakim memiliki perspektif yang cakupannya bukan hanya bersifat inconcrito pada suatu kasus tertentu saja, akan tetapi juga menjangkau perspektif yang dapat dijadikan landasan bagi perkembangan hukum, khususnya hukum perjanjian.Hal inidikarenakan hasil penemuan hukum oleh hakim baik itu dengan menggunakan metode penemuan hukum melalui penafsiran hukum, maupun metode konstruksi hukum mela.l-Urkan kaidahkaidah hukum tertentu dan dalam putusan hakim tersebut di dalamnya terdapat anotasi putusan yang mencerminkan perwujudan dari tujuan hukum, yaitu keadilan, kepastian hukum serta kemanfaatan. Untuk mengatasi jika terjadinya bentuk-bentuk kekosongan hukum (recht vaccum) dan kekosongan undang-undang (wet Vaccum). Selain itu, Anotasi putusan hakim merupakan inti dari proses penemuan hukum oleh hakim dan dapat dikatakan sebagai output dari penemuan hukum oleh hakim dimaksud. Anotasi putusan akan selalu mencerminkan implementasi nyata dari tujuan hukum yang dikenalluas dalam masyarakat, yaitu keadilan, kepastian hukum dan kemanfaatan. Ketiga tujuan hukum itu memang jarang ada dalam suatu putusan hakim secara bersamaan, namun salah satu tujuan hukum itu akan diterapkan oleh hakim sebagai anotasi putusannya.

\section{Referensi}

Amos, H. F. Abraham. (2008) Legal Opinion: Aktualisasi Teoritis dan Empiris. Jakarta: Rajawali Press.

Ardhiwisastra, Yudha Bhakti. (2008) Penafsiran dan Konstruksi Hukum. Bandung: PT.Alwnni.

Darmodiharjo, Darji dan Shidarta, (2008) Pokokpokok Filsafat Hukum, Apa dan Bagaimana Filsafat Hukum Indonesia. Jakarta: Gramedia Pustaka Utama.

Hamidi, Jazim, (2005) Hermenuetika Hukum: Teori Penemuan Hukum Baru dengan Interprestasi Teks. Yogyakarta:UII Press.

Hiariej, Eddy O.S. (2009) Asas Legalitas dan Penemuan Hukum Dalam Hukum Pidana. Jakarta: Erlangga.

Loudoe, Jhon Z. (1985) Menemukan Hukum melalui Tafsir dan Fakta.Jakarta: Bina Aksara.

Mertokusumo, Sudikno (2009) Pene;nuan Hukum: Suatu Pengantar. Yogyakarta:Liberty.

Mertokusumo,Sudikno dan A Pitlo. (1993) Bab-Bab Tentang Penemuan Hukum. Bandung: PT.Citra Aditya Bakti.

Moerad, B. M., Pontang. (2005) Pembentukan Hukum Melalui Putusan Pengadilan dalam Perkara Pidana.Bandung: PT.Alumni.

Monteiro, J.M. (2007) Putusan Hakim Dalam Penegakan Hukum Di Indonesia. Jurnal Hukum Pro Justisia.Vol.25, No.2, pp.130-139.

Nasution, Bahder Johan. (2008) Metode Penelitian Ilmu Hukum. Bandung: CV. Mandar Maju. 
Pangabean, Henry P., (2008) Peran Makamah Agung Melalui Putusan-Putusan Hukum Perikatan. Bandung:PT. Alumni.

Pound, Roscoe, (1973) Suatu Pengantar ke filsafat Hukum.Terj.K. Radjab. Jakarta: Bharata.

Rahardjo, Satjipto (2006) Ilmu Hukum. Bandung: Penerbit Alumni.

Republi.k Indonesia, Undang-Undang Nomor.3 Tahun 2009, Tentang Perubahan Kedua UndangUndang Makamah Agung

Republik Indonesia, Undang-Undang Nomor.48 Tahun 2009, tentang Perubahan UndangUndang Kekuasaan Kehakiman, Jakarta, Sinar Grafika.

Republik Indonesia, Undang-Undang Nomor.49 tahun 2009, Tentang Perubahan UndangUndang Peradilan Umum

Rifai, Ahmad, (2010) Penemuan Hukum Oleh Hakim dalam PerspektifHukum Progresif. Jakarta:Sinar Grafika.

Satjipto, Rahardjo. (2009) Hukum Progresif: Sebuah Sintesa Hukum Indonesia, Yogyakarta: Genta Publishing.

Sutiyoso, Bambang. (2006) Metode Penemuan Hukum: Upaya Mewujudkan Hukum yang pasti dan berkeadilan. Yogyakarta: UTI Press. 